\title{
Premature Rupture of Membrane (PROM) Increasing Asphyxia Neonatorum Risk
}

\author{
$1^{\text {st }}$ Efrida Yusriyanti Syamsi \\ Faculty of Health Sciences \\ Universitas Aisyiyah Yogyakarta \\ Yogyakarta, Indonesia
}

\author{
$* 2^{\text {nd }}$ Nuli Nuryanti Zulala \\ Faculty of Health Sciences \\ Universitas Aisyiyah Yogyakarta \\ Yogyakarta, Indonesias \\ nuli.zulala@unisayogya.ac.id
}

\begin{abstract}
According to WHO, 4 million infants die annually from asphyxia at birth, which represents about $38 \%$ of all children's death under 5 years. The incidence of premature rupture of the membranes (PROM) occurs in 6$20 \%$ of pregnancies. The most common complication in PROM is respiratory distress syndrome, which takes place in $10-40 \%$ of newborns and causes hypoxia and asphyxia. The study aims to identify the relations of premature rupture of membrane (PROM) with asphyxia neonatorum. The methods used observational analytic correlation with a case-control design and chi-square analysis. The sample of this study accounted for 144 respondents, composing of 72 people of the case group and 72 people of the control group. The results of the chi-square test showed p-value 0.024, $\mathrm{CI}=1,108-4,496, \mathrm{OR}=2,232$ and the value of the correlation coefficient was 0.185 .
\end{abstract}

Keywords- Asphyxia Neonatorum, Premature Rupture of Membrane

\section{INTRODUCTION}

The first 28 days of a newborn's life is the most vulnerable time for a child's survival. In 2016, there were 2.6 million infants died, and approximately $46 \%$ of them died in the neonatal period, indicating that 7,000 babies were dying every day [1]. One of the causes of newborn death in Indonesia is asphyxia, which, despite equal to $27 \%$, is the second most lethal cause of newborn death after Low Birth Weight Babies (LBW) [2].

The cause of perinatal asphyxia can be seen from the mother and fetus. Asphyxia at birth can allow neurological complications, including epilepsy, cerebral palsy, and developmental delay. Risk factors for asphyxia in newborns can be seen in the antepartum, intrapartum, and fetus [3].

Some factors that affect asphyxia in newborns include; a) maternal factors, namely post-term, hypertension, preeclampsia, premature rupture of membranes; b) the factors of labor, namely prolonged labor, breech presentation, cesarean section delivery; c) fetal factors, namely premature, umbilical cord; and d) placental factors, namely abruptio placenta, placenta previa

Premature rupture of membranes occurs in 6-20\% of pregnancies. Premature rupture of membranes is very influential in pregnancy and childbirth. The longer the distance of the rupture of the membranes, the more likely the infection in the uterus increases the incidence of maternal and infant morbidity and mortality. This is because of the importance of PROM and its effect on pregnancy outcomes and related maternal and neonatal complications [4].

Premature rupture of membrane (PROM) is a complication associated with preterm pregnancy and has a substantial contribution to the perinatal mortality rate in preterm infants. PROM had a significant relation to earlyonset sepsis in preterm infants, and it is associated with lower incidences of transient tachypnea of newborn and respiratory distress syndrome [5]. Birth asphyxia is a severe clinical problem worldwide and contributes significantly to neonatal mortality and morbidity [6].

\section{RESULT}

Table 1 shows that 55 respondents (38.2\%) who experienced asphyxia were born from mothers aged 20-35 years, while 35 respondents $(24.3 \%)$ were born from mothers with primiparous and multiparous parity. Furthermore, 41 people $(28.5 \%)$ were delivered by mothers with secondary education, 40 respondents $(27.8 \%)$ from mothers who work, and 62 respondents were born at the age of term pregnancy $(43.1 \%)$.

TABLE I. CHARACTERISTICS OF RESPONDENTS WHO HAVE ASPHYXIA

\begin{tabular}{|c|c|c|c|c|c|c|}
\hline \multirow{3}{*}{ Characteristics } & \multicolumn{4}{|c|}{ Asphyxia } & \multicolumn{2}{|c|}{ Total } \\
\hline & \multicolumn{2}{|c|}{ Asphyxia } & \multicolumn{2}{|c|}{ No Asphyxia } & \multirow[b]{2}{*}{$\mathbf{F}$} & \multirow[b]{2}{*}{$\%$} \\
\hline & $\mathbf{F}$ & $\%$ & $\mathbf{F}$ & $\%$ & & \\
\hline \multicolumn{7}{|l|}{$\begin{array}{l}\text { Age } \\
\text { pregnant } \\
\text { women }\end{array}$} \\
\hline$<20$ years old & 2 & $1.4 \%$ & 6 & $4.2 \%$ & 8 & $5.6 \%$ \\
\hline 20-35 years old & 55 & $38.2 \%$ & 53 & $36.8 \%$ & 108 & $75 \%$ \\
\hline$>35$ years & 15 & $10.4 \%$ & 13 & $9 \%$ & 28 & $19.4 \%$ \\
\hline Total & 72 & $50 \%$ & 72 & $50 \%$ & 144 & $100 \%$ \\
\hline \multicolumn{7}{|l|}{ Parity } \\
\hline Primipara & 35 & $24.3 \%$ & 32 & $22.2 \%$ & 67 & $46.5 \%$ \\
\hline Multipara & 35 & $24.3 \%$ & 37 & $25.7 \%$ & 72 & $50 \%$ \\
\hline $\begin{array}{l}\text { Grande } \\
\text { multipara }\end{array}$ & 2 & $1.4 \%$ & 3 & $2.1 \%$ & 5 & $3.5 \%$ \\
\hline Total & 72 & $50 \%$ & 72 & $50 \%$ & 144 & $100 \%$ \\
\hline \multicolumn{7}{|l|}{ Education } \\
\hline Basic & 2 & $1.4 \%$ & 6 & $4.2 \%$ & 8 & $5.6 \%$ \\
\hline Intermediate & 41 & $28.5 \%$ & 36 & $25 \%$ & 77 & $53.5 \%$ \\
\hline High & 29 & $20.1 \%$ & 39 & $20.8 \%$ & 59 & $41 \%$ \\
\hline Total & 72 & $50 \%$ & 72 & $50 \%$ & 144 & $100 \%$ \\
\hline
\end{tabular}




\begin{tabular}{lcccccc} 
Work & 40 & $27.8 \%$ & 43 & $29.9 \%$ & 83 & $57.6 \%$ \\
Does not work & 32 & $22.2 \%$ & 29 & $20.1 \%$ & 61 & $42.4 \%$ \\
Total & 72 & $50 \%$ & 72 & $50 \%$ & 144 & $100 \%$ \\
$\begin{array}{l}\text { Age of } \\
\text { Pregnancy }\end{array}$ & & & & & & \\
Preterm & 10 & $6.9 \%$ & 1 & $0.7 \%$ & 11 & $7.6 \%$ \\
Aterm & 62 & $43.1 \%$ & 71 & $49.3 \%$ & 133 & $92.4 \%$ \\
Postterm & - & - & - & - & - & - \\
Total & 72 & $50 \%$ & 72 & $50 \%$ & 144 & $100 \%$ \\
\hline
\end{tabular}

TABLE II. Results of Cross TABUlation AND ChI-SQuare Test

\begin{tabular}{lcccccc}
\hline Asphyxia & Yes & Not & Total & & & \\
& & & & P. & Koe- & OR \\
Y & $\mathbf{F}$ & $\mathbf{F}$ & $\mathbf{F}$ & & & \\
Yes & $(\boldsymbol{\%})$ & $(\boldsymbol{\%})$ & $(\boldsymbol{\%})$ & & & \\
\multirow{2}{*}{ No } & 32 & 19 & 51 & & & 2,23 \\
& $(22.2)$ & $(13.2)$ & $(35.4)$ & & & 2 \\
Total & 40 & 53 & 93 & 0.024 & .185 & \\
& $(27.8)$ & $(36.8)$ & $(64.6)$ & & & \\
\hline
\end{tabular}

Based on table 2, it can be seen that there were 51 respondents with PROM (35.4\%), consisting of 32 respondents $(22.2 \%)$ who experienced asphyxia and 19 respondents who did not experience asphyxia (13.2\%). Respondents who did not experience PROM were 93 people (64.6\%), consisting of 40 respondents (27.8\%) who experienced asphyxia and 53 respondents who did not experience asphyxia $(36.8 \%)$.

Bivariate analysis results demonstrate that the p-value of this study was 0.024 , with an odds ratio (OR) of 2.232. The correlation coefficient value in this study was 0.185 .

\section{DISCUSSION}

Maternal risk factors of PROM include age, parity, education, occupation, diabetes, blood pressure, the cervical length along with abortion history, the history of infection, upper urinary tract infection, and sexually transmitted diseases. Moreover, delivery complications were cesarean section, oligohydramnios, chorioamnionitis, and placental abruption. Neonatal complications include prematurity, respiratory distress syndrome, asphyxia, infection, meningitis, sepsis, pneumonia, perinatal mortality, patent arterial duct, necrotizing enterocolitis, IVH, pulmonary hypoplasia, hyperbilirubinemia, and antibiotic intake [7]

Risk factors for asphyxia in newborns include antepartum and intrapartum factors. An intrapartum risk factor that causes asphyxia in newborns is PROM [8].

Based on Mohammed (2016), in India, PROM has 3\% of maternal risk factors for newborns requiring resuscitation [9]. The incidence of term PROM in East China is approximately $12.5 \%$. The mothers in the PROM group has a higher incidence of bacterial vaginitis (BV), chlamydia trachomatis (CT) infection, postpartum hemorrhage, and cesarean section deliveries. Infants in the PROM group experiences higher rates of infection, asphyxia, and jaundice [10].

PROM affects asphyxia due to oligohydramnios that presses on the umbilical cord so that the umbilical cord is constricted, and blood flow that carries maternal oxygen to the baby is obstructed, causing asphyxia or hypoxia. There is a relationship between fetal distress and the degree of oligohydramnios, the less the amniotic fluid, the fetus is found in both worsening field or at a referral hospital in Indonesia [8].

In a study conducted by Linehan et al. (2016), mothers who give birth with premature rupture of membranes have an impact on the complications of the babies born. In that situation, all babies transferred to the NICU have significant respiratory morbidity and are managed with mechanical ventilation, nitric oxide, and surfactants. This study concludes that every mother who gives birth with complications of premature rupture of membranes have high neonatal mortality [11].

The results of this study showed that the incidence number of asphyxia neonatorum was 72 cases or reached 9.6\% of all newborns. According to Prawirohardjo (2010), asphyxia neonatorum can cause brain damage and death because of progressive hypoxia, $\mathrm{CO} 2$ accumulation, and long-lasting acidosis [12]. Consequently, asphyxia neonatorum cases need special attention because, according to WHO (2016), in low-income countries, $23 \%$ of deaths in newborns are caused by asphyxia [1]

Aslam et al. (2015) show that the factors that influence the occurrence of asphyxia in newborns are caused by antepartum factors, intrapartum factors, and fetal risk factors. That study explains that among intrapartum risk factors that can cause asphyxia in newborns is PROM, which has a significant relationship with $\mathrm{p}=0.01[3]$.

Based on the analysis of the test with the chi-square test, it can be seen that there was a significant relationship between PROM with the incidence of asphyxia neonatorum. This study is in line with the research of Yadav \& Sachin (2017), which states that there is a significant relationship between PROM with the incidence of asphyxia in newborns $(\mathrm{RR}=3.2$ CI 1.5-6.7) [6]

Nikita et al. (2017) demonstrate that birth asphyxia occurred in $15.0 \%$ infants in the PROM group and $6.8 \%$ infants in the non-PROM group $(\mathrm{P}<0.001)$. RDS was seen in $9.8 \%$ of infants in women with PROM. The incidence of RDS was $5.2 \%$ in full-term infants and $11.6 \%$ in premature infants [13].

Kardana (2016) also shows that perinatal asphyxia is a leading cause of mortality and morbidity in neonates in developing countries, with an incidence of 1 to 6 per 1,000 live full-term births. It is the second most common cause of neonatal death in Indonesia. Antepartum and intrapartum risk factors have been shown to be associated with perinatal asphyxia. PROM has OR 10.61 (95\%CI 1.81-62.08 p=0.009) and are significant risk factors of perinatal asphyxia in a term newborn [14].

Furthermore, Yadav and Damke (2017) show PROM as one of the factors causing asphyxia. Asphyxia results in hypoxemia (lack of oxygen) and hypercapnia (accumulation of carbon dioxide). The combination of the decrease in oxygen supply (hypoxia) and blood supply (ischemia) results in a cascade of biochemical changes inside the body, whose events lead to neuronal cell death and brain damage. Continuous asphyxia also leads to multiple organ systems dysfunction [6]. 
PROM can be prevented by preventing infection by correct health workers, counseling about healthy living habits such as not smoking, consuming healthy food, drinking enough, and exercising regularly [15].

Regular antenatal care at least 4 times, 1 in the first trimester, 1 in the second trimester and 2 times in the third trimester and the mother must also pay attention to her health in order to prevent abnormalities during pregnancy so that later there will be no complications during labor and reduce the risk of occurrence asphyxia [16].

\section{CONCLUSION}

Premature rupture of membrane (PROM) increase the risk of asphyxia neonatorum by two times.

\section{REFERENCES}

[1] WHO, Neonatal Mortality Situation and Trends. 2016

[2] Kementerian Kesehatan RI, Profil Kesehatan Indonesia Tahun 2017. 2017.

[3] H. M. Aslam et al., "Risk Factors of Birth Asphyxia "," Ital. J. Pediatr., pp. 1-9, 2014.

[4] H. Boskabadi, G. Maamouri, and S. Mafinejad, "Neonatal Complications Related with Prolonged Rupture of Membranes," Maced. J. Med. Sci., vol. 4, no. 1, pp. 93-98, 2011.

[5] E. Altuncu, S. Kavuncuoðlu, and Z. Albayrak, "The Effect Of Premature Rupture Of Membranes To The Morbidity And Mortality Of Preterm Babies," Zeynep Kamil Tip Bul., pp. 179-183, 2005.

[6] N. Yadav and S. Damke, "Study of Risk Factors in Children with Birth Asphyxia," Int. J. Contemp. Pediatr., vol. 4, no. 2, pp. 518-526, 2017.
[7] H. Boskabadi and Z. Maryam, "Review Article: Evaluation of Maternal Risk Factors, Delivery, and Neonatal Outcomes of Premature Rupture of Membrane: A Systematic Review Study," J. Pediatr. Rev., vol. 7, no. 2, pp. 77-88, 2019.

[8] V. Chapman and C. Charles, Birth and Labor. EGC, 2013.

[9] M. As and S. Tarannum, "Risk Factors of Birth Asphyxia in Neonates," Pediatr. Rev. Int. J. Pediatr. Res., vol. 5, no. 12, pp. 603608, 2018.

[10] H. Xia, X. Li, X. Li, H. Liang, and H. Xu, "The Clinical Management and Outcome of Term Premature Rupture of Membrane in East China : Results from a Retrospective Multicenter Study," Int. J. Clin. Exp. Med., vol. 8, no. 4, pp. 6212-6217, 2015.

[11] L. A. Linehan et al., "Neonatal and Maternal Outcomes Following Midtrimester Preterm Premature Rupture of The membranes: A Retrospective Cohort Study," BMC Pregnancy Childbirth, pp. 1-7, 2016.

[12] P. Sarwono, Ilmu Kebidanan. Jakarta: Yayasan Bina Pustaka Sarwono Prawiroardjo, 2017.

[13] J. Nikita, P. Reena, K. P. Banerjee, R. Lata, and G. Disha, "A Study of Perinatal Outcome in Premature Rupture of Membrane," Sch. J. Appl. Med. Sci., vol. 5, pp. 1391-1395, 2017.

[14] I. M. Kardana, "Risk Factors of Perinatal Asphyxia in The Term Newborn at Sanglah General Hospital , Bali-Indonesia," Bali Med. J., vol. 5, no. 1, pp. 196-199, 2016.

[15] World Health Organization (WHO), WHO Recommendations on Antenatal Care For A Positive Pregnancy Experience. 2016.

[16] Kemenkes RI, "Peraturan Menteri Kesehatan Republik Indonesia Nomor 97 Tahun 2014 Tentang Pelayanan Masa Sebelum Hamil, Masa Hamil, Persalinan dan Masa Sesudah Melahirkan, Penyelenggaraan Pelayanan Kontrasepsi Serta Pelayanan Kesehatan Seksual." 2014. 